Review

\title{
Obesity and Dyslipidemia in South Asians
}

\author{
Anoop Misra ${ }^{1,2,3, *}$ and Usha Shrivastava ${ }^{3}$
}

1 Fortis-C-DOC Centre of Excellence for Diabetes, Metabolic Diseases and Endocrinology, B-16, Chirag Enclave, New Delhi 110048, India

2

Diabetes Foundation (India), New Delhi 110016, India

3 National Diabetes, Obesity and Cholesterol Foundation (N-DOC), New Delhi 110016, India; E-Mail: usha.shrivast@gmail.com

* Author to whom correspondence should be addressed;

E-Mail: anoopmisra@metabolicresearchindia.com; Tel.: +011-493-01222; Fax: +011-493-01200.

Received: 1 May 2013; in revised form: 22 May 2013 / Accepted: 28 May 2013 /

Published: 16 July 2013

\begin{abstract}
Obesity and dyslipidemia are emerging as major public health challenges in South Asian countries. The prevalence of obesity is more in urban areas than rural, and women are more affected than men. Further, obesity in childhood and adolescents is rising rapidly. Obesity in South Asians has characteristic features: high prevalence of abdominal obesity, with more intra-abdominal and truncal subcutaneous adiposity than white Caucasians. In addition, there is greater accumulation of fat at "ectopic" sites, namely the liver and skeletal muscles. All these features lead to higher magnitude of insulin resistance, and its concomitant metabolic disorders (the metabolic syndrome) including atherogenic dyslipidemia. Because of the occurrence of type 2 diabetes, dyslipidemia and other cardiovascular morbidities at a lower range of body mass index (BMI) and waist circumference (WC), it is proposed that cut-offs for both measures of obesity should be lower (BMI $23-24.9 \mathrm{~kg} / \mathrm{m}^{2}$ for overweight and $\geq 25 \mathrm{~kg} / \mathrm{m}^{2}$ for obesity, WC $\geq 80 \mathrm{~cm}$ for women and $\geq 90 \mathrm{~cm}$ for men for abdominal obesity) for South Asians, and a consensus guideline for these revised measures has been developed for Asian Indians. Increasing obesity and dyslipidemia in South Asians is primarily driven by nutrition, lifestyle and demographic transitions, increasingly faulty diets and physical inactivity, in the background of genetic predisposition. Dietary guidelines for prevention of obesity and diabetes, and physical activity guidelines for Asian Indians are now available. Intervention programs with emphasis on improving knowledge, attitude and practices regarding healthy nutrition, physical activity and stress management need to be implemented. Evidence for
\end{abstract}


successful intervention program for prevention of childhood obesity and for prevention of diabetes is available for Asian Indians, and could be applied to all South Asian countries with similar cultural and lifestyle profiles. Finally, more research on pathophysiology, guidelines for cut-offs, and culturally-specific lifestyle management of obesity, dyslipidemia and the metabolic syndrome are needed for South Asians.

Keywords: obesity; abdominal obesity; dyslipidemia; triglycerides; Asian Indians; high density lipoprotein cholesterol (HDL); South Asians; nutrition; physical activity; type 2 diabetes

\section{Introduction}

Non-communicable diseases (NCDs) are emerging as a major health challenge in South Asians, which encompass residents of India, Pakistan, Bangladesh, Sri Lanka, Nepal, Bhutan and Maldives, constituting $24 \%$ of the world's population [1]. According to the World Health Organization, NCDs including type 2 diabetes mellitus (T2DM), cardiovascular diseases (CVDs), chronic obstructive airways disease (COPD), cancer, injuries and mental disorders are the cause of 52\% mortality, and are going to account for $72 \%$ of total mortality by 2030 in South Asia [2-5].

Globally, prevalence of obesity has doubled in the last two decades. In 2008, more than 1.6 billion adults over 20 years were overweight, of these, over 200 million men and nearly 300 million women were obese [6-8]. About $44 \%$ of the diabetes burden and $23 \%$ of the CVD burden is attributable to overweight and obesity; and mortality due to obesity occurs in 2.8 million adults each year [7,9-13]. Further, more than 43 million children under the age of five were overweight in 2010 [6]. It has been observed that $65 \%$ of the world's population lives in countries where overweight and obesity are responsible for higher mortality than is underweight.

Obesity is associated with several co-morbid conditions: dyslipidemia, hypertension, hyperglycemia, non-alcoholic fatty liver disease (NAFLD) and a conglomeration of conditions known as the metabolic syndrome. Almost one third of the population of developed countries is detected to be having dyslipidemia $[14,15]$; however, prevalence varies depending on ethnic group studied. There is a wide variation in the prevalence of dyslipidemia in India depending on habitat, socioeconomic stratum and lifestyle practices [16].

\section{Definitions}

"South Asians" denote residents of India, Pakistan, Bangladesh, Sri Lanka, Nepal, Bhutan and Maldives constituting $24 \%$ of the world's population. "Asian Indians" is a term used by authors to denote people with Indian origin. The U.S. Census Bureau uses the term Asian Indian to avoid confusion with the indigenous peoples of the Americas commonly referred to as American Indians. A "slum", for the purpose of Census, has been defined as residential areas where dwellings are unfit for human habitation by reasons of dilapidation, overcrowding, faulty arrangements and design of such 
buildings, narrowness or faulty arrangement of street, lack of ventilation, light, or sanitation facilities or any combination of these factors which are detrimental to the safety and health [17].

\section{Search Strategy}

The medical search engines, Pub med (National Library of Medicine, Bethesda, MD, USA) and Google Scholar; and Governmental websites of South Asians were used for literature search using the key words, "Obesity, abdominal obesity, overweight, dyslipidemia, type 2 diabetes mellitus, insulin resistance, coronary heart disease, cholesterol, triglycerides, low density lipoprotein cholesterol (LDL), high density lipoprotein cholesterol (HDL), adipose tissue, non-alcoholic fatty liver disease, intra myocellular lipids, adipocyte, South Asians, and Asian Indians" from 1966 to December 2012. A total of 1024 references were extracted and studied. A total of 147 relevant references are being quoted. The references include reports from international and national organizations [18], chapters from books [3], review articles [19], cross-sectional studies [20], prospective studies [9] and intervention trials [7].

\section{Guidelines for Diagnosis of Obesity}

Various studies have shown that South Asians are at risk of developing obesity related co-morbidities at lower levels of body mass index (BMI) and waist circumference (WC), and that they have higher body fat at a given value of BMI than white Caucasians [21-24]. Based on these reports, it has been debated whether BMI cut-offs for diagnosis of overweight and obesity should be lower for Asian populations as compared to the available international guidelines [9,23-27]. In 2004, a WHO expert Consultative Committee opined that Asian populations have different associations between BMI, percentage of body fat and health risks than do European populations and suggested BMI cut-offs as $\geq 23-24.9 \mathrm{~kg} / \mathrm{m}^{2}$ and $\geq 25 \mathrm{~kg} / \mathrm{m}^{2}$ for overweight and obesity, respectively [26]. Subsequently, this issue has been intensively debated [24,25,27]. In an article, the WHO group discussed that no firm action should be taken internationally, and left the decision for guidelines for BMI to the governments of respective Asian countries at that time [18].

Subsequently, a Consensus Group from India formulated revised guidelines for BMI for Asian Indians (Table 1) [28]. Similar to BMI related data, cardiovascular morbidities occur at lower value of WC in Asian Indians [27], and most of the researchers have felt a need to revise international guidelines for WC for South Asians. It is important to note that International Diabetes Federation (IDF) and National Cholesterol Education Program, Adults Treatment Panel III (NCEP, ATP III) in their recent definitions of the metabolic syndrome have taken the ethnic-specific cut-off points for WC into consideration [23-25,29-31]. 
Table 1. Cut-offs of obesity and abdominal obesity for Asian Indians vs. international criteria.

\begin{tabular}{ccc}
\hline Variable & $\begin{array}{c}\text { Consensus guidelines } \\
\text { for Asian Indians }\end{array}$ & $\begin{array}{c}\text { Prevalent International } \\
\text { Criteria }\end{array}$ \\
\hline Generalized obesity & Normal: $18.0-22.9$ & Normal: $18.5-24.9^{\mathrm{b}}$ \\
$\left(\right.$ BMI cut-offs in $\left.\mathrm{kg} / \mathrm{m}^{2}\right)$ & Overweight: $23.0-24.9$ & ${\text { Overweight: } 25.0-29.9^{\mathrm{b}}}^{\mathrm{a}}$ \\
Abdominal obesity (Waist & Obesity: $\geq 25$ & Obesity: $\geq 30^{\mathrm{b}}$ \\
circumference cut-offs in cm) & Men: $\geq 90^{\mathrm{c}}$ & Men: $\geq 102^{\mathrm{d}}$ \\
\hline
\end{tabular}

Notes: ${ }^{\text {a }}$ From Consensus guidelines for Asian Indians [28]; ${ }^{\text {b }}$ According to World Health Organization guidelines [32]; ${ }^{\mathrm{c}}$ Both as per Consensus Guidelines for Asian Indians [28] and International Diabetes Federation [33]; ${ }^{\mathrm{d}}$ According to Modified National Cholesterol Education Program, Adult Treatment Panel III guidelines [34]; Adapted from [27].

\section{Prevalence}

\subsection{Generalized Obesity}

The prevalence of obesity in South Asians varies according to the age, gender, place of residence, socio-economic status, and criteria used for the measurement of obesity. In general, increasing prevalence of obesity has been seen in all studies carried out in India and other South Asian countries as shown in Table 2.

Table 2. Prevalence of obesity in South Asians.

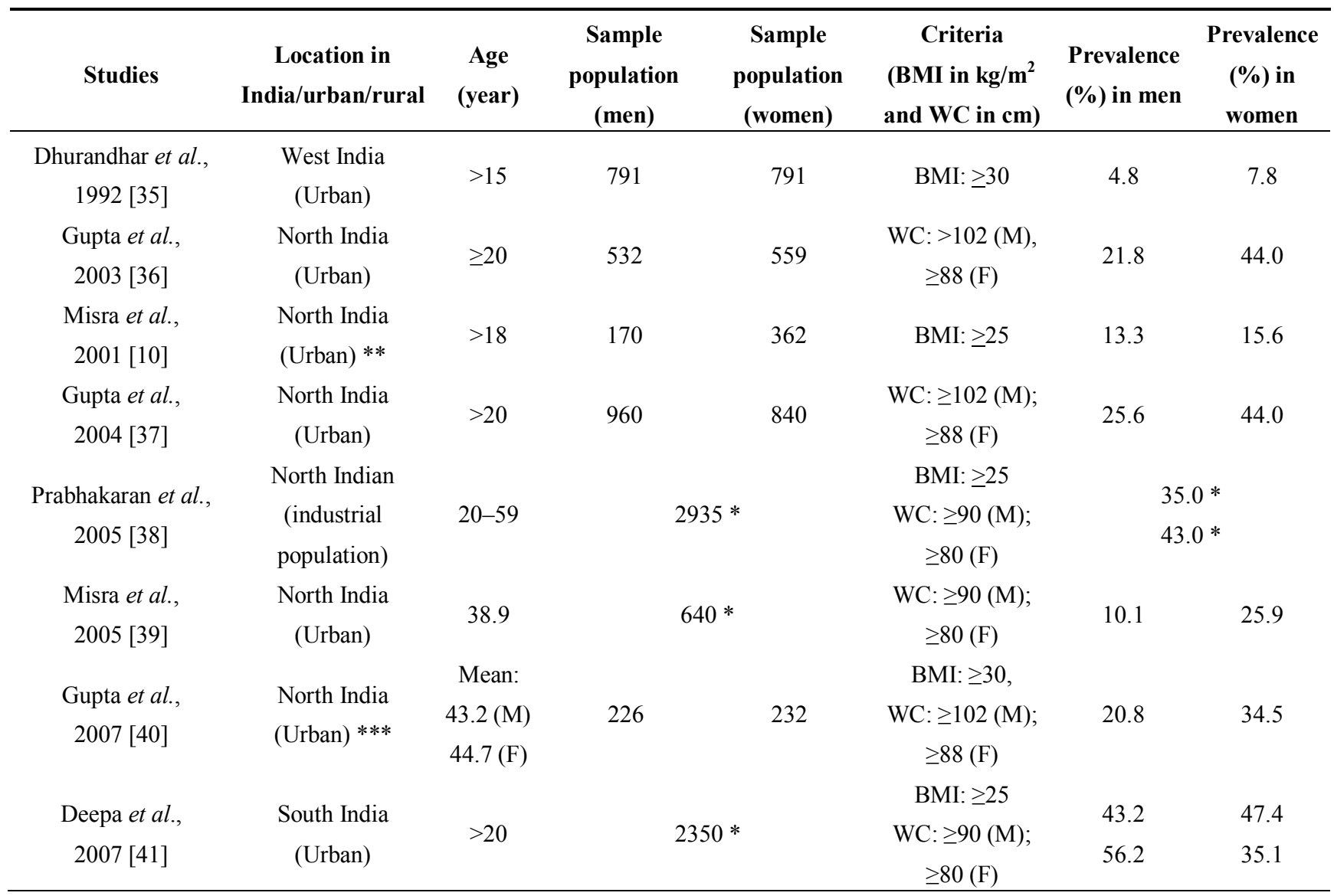


Table 2. Cont.

\begin{tabular}{|c|c|c|c|c|c|c|c|}
\hline $\begin{array}{l}\text { Wijewardene et al., } \\
2008[42]\end{array}$ & Sri Lanka & $30-65$ & 2692 & 3355 & BMI: $\geq 25$ & 20.3 & 36.5 \\
\hline $\begin{array}{c}\text { Zaman et al., } \\
2001[43]\end{array}$ & $\begin{array}{c}\text { Bangladesh } \\
\text { (Rural) }\end{array}$ & $>18$ & 238 & 272 & $\begin{aligned} \mathrm{WC} & : \geq 94(\mathrm{M}) \\
& \geq 80(\mathrm{~F})\end{aligned}$ & 2.9 & 16.8 \\
\hline Nanan [44] & Pakistan & $25-64$ & \multicolumn{2}{|c|}{ National Survey } & BMI: $>30$ & 13 & 23 \\
\hline $\begin{array}{l}\text { Vaidya et al., } \\
2008[45,46]\end{array}$ & $\begin{array}{l}\text { Kathmandu, } \\
\text { Nepal (urban) }\end{array}$ & $21-57$ & 341 & & BMI: > 25 & 33 & \\
\hline $\begin{array}{c}\text { Chow et al., } \\
2008 \text { [47] }\end{array}$ & $\begin{array}{l}\text { South India } \\
\quad \text { (rural) }\end{array}$ & $20-90$ & & & $\begin{array}{c}\text { BMI: }>25 \\
\text { WC: } \geq 90(\mathrm{M}) \\
\quad \geq 80(\mathrm{~F})\end{array}$ & 32.4 & 41.4 \\
\hline $\begin{array}{c}\text { Bhardwaj et al., } \\
2011 \text { [48] }\end{array}$ & $\begin{array}{l}\text { North India } \\
\text { (urban) }\end{array}$ & $>18$ & 217 & 242 & $\begin{array}{c}\text { BMI: }>25, \\
\text { WC: } \geq 90(\mathrm{M}) \\
\quad \geq 80(\mathrm{~F})\end{array}$ & 50.2 & 50 \\
\hline $\begin{array}{c}\text { Gupta et al., } \\
2011 \text { [49] }\end{array}$ & $\begin{array}{l}\text { West India } \\
\text { (Urban) }\end{array}$ & $35-70$ & 4621 & & $\begin{aligned} \mathrm{WC} & : \geq 102(\mathrm{M}) ; \\
& \geq 88(\mathrm{~F})\end{aligned}$ & 14.4 & \\
\hline
\end{tabular}

Notes: * Overall including male and female; ** Data from urban slum population of New Delhi, north India; *** Data from Punjabi Bhatia community in north India; M, Male; F, Female; BMI, Body mass index; WC, Waist circumference; Adapted from [9].

There are some countries in South Asia with low mean BMI values, e.g., Bangladesh (estimated mean BMI in 2008 was less than $21 \mathrm{~kg} / \mathrm{m}^{2}$ ). However, the recent trends indicate increase in the prevalence of overweight and obesity since 1990s even in Bangladesh and Nepal [50] (Table 2).

\subsection{Urban}

The prevalence rates of obesity are higher in urban areas as compared to the rural areas, since these are most affected by rapid changes in nutritional pattern and sedentary life style $[9,27,51]$. In 2003, the prevalence of obesity was $13.5 \%$ (10\% in men and $15.1 \%$ in women) in New Delhi (north India) [10]. In 2004, overweight (BMI $\geq 25 \mathrm{~kg} / \mathrm{m}^{2}$ ) was present in $54.0 \%$ men and $69.4 \%$ women, while obesity $\left(\mathrm{BMI} \geq 30 \mathrm{~kg} / \mathrm{m}^{2}\right.$ ) was present in $20.8 \%$ men and $32.3 \%$ women in Jaipur city in Western India [19]. In a recent study by our group on urban adult population in New Delhi (north India), the prevalence of obesity was observed to be $50.1 \%(50.2 \%$ in males and $50.0 \%$ in females) [48].

\subsection{Rural}

In 1997, prevalence of obesity was reported as $8 \%$ in rural north India [52]. However, in 2008, in rural areas in Andhra Pradesh in south India, the prevalence figures for overweight were 32.4\% in men and $41.4 \%$ in women using Asian cut offs [47]. In a study in rural Tamilnadu (south India) in 2012 using Asian cut offs for obesity, the prevalence was reported to be as high as $32.8 \%$ in males and $38.2 \%$ in females [53]. 


\subsection{Abdominal Obesity}

Various studies have shown high prevalence of abdominal obesity in South Asians. In this ethnic group, abdominal obesity has been recognized as an important risk factor for T2DM, the metabolic syndrome and CVD [9,54-56]. In southern part of India (Tamilnadu), using Asian cut offs, abdominal obesity was present in $17.6 \%$ males and $23.7 \%$ females [53]. In a recent study on urban population of Delhi, abdominal obesity was observed in $68.9 \%$ subjects (62.2\% males and $74.8 \%$ females) [48]. A high prevalence of abdominal obesity was shown even in underprivileged population of urban slums as well [10].

\subsection{Obesity in Women}

The available data suggest that South Asian women are comparatively more obese than men. The rise in the prevalence of overweight and obesity in women in India is reflected in the report of the National Family Health Survey (NHFS; NHFS-2 (1998-1999; conducted on 90,000 women in the age group of 15-49 years in 26 states), and NHFS-3 (2005-2006, conducted on 124,385 women in 29 states) [57,58]. The NHFS-3 data (WHO cut offs for obesity used) showed that $24 \%$ of urban women were obese as compared to $9.4 \%$ in NFHS-2. In rural areas, the prevalence has risen from $2.6 \%$ in NFHS-2 to $7 \%$ in NFHS-3 [57-59]. These women belonged to different socio-economic strata, and had varied educational and occupational backgrounds and differing caste, community and religion. According to our previous study on post-menopausal women residing in urban slums in New Delhi, overweight and abdominal obesity were present in $23.7 \%$ and $28 \%$ of women, respectively [10]. In a recent multi-site study conducted on 4608 women over 35 years of age in India, using WHO cut offs, $33.2 \%$ rural women were overweight as compared to $46.6 \%$ of the urban women as shown in Table 2 [49].

\subsection{Obesity in Children/Adolescents}

There is a wide variation in the prevalence data for childhood obesity globally. In 2010,43 million children (35 million in developing countries) were estimated to be overweight and 92 million were at risk of being overweight [6]. The worldwide prevalence of childhood overweight and obesity increased from $4.2 \%$ (95\% CI: $3.2 \%, 5.2 \%$ ) in 1990 to $6.7 \%$ (95\% CI: $5.6 \%, 7.7 \%$ ) in 2010. Data from many developing countries show an increase in prevalence of obesity in children and adolescents [60-66].

The prevalence of overweight/obesity in urban post-pubertal children in Delhi showed an increase from $16 \%$ in 2002 to about $24 \%$ in 2006 [63]. A high prevalence was seen in the private schools (catering to children from upper socio-economic stratum) $29 \%$ vs. $11 \%$ in government schools (catering to lower socio-economic stratum) [60-66]. In a recent study by our group conducted on nearly 38,000 children across five Indian cities: New Delhi, Jaipur, Agra (north), Allahabad (central) and Mumbai (west), prevalence of overweight was $14.4 \%$ and obesity $2.8 \%$ according to International Obesity Task Force cutoffs [66]. Further, abdominal obesity was higher in girls than in boys $(p<0.001)$, being the highest in 8-year-old females (18.6\%) [63-66]. Secular trends were observed among urban north Indian adolescents over a period of 5 years (2003-2008). A significant increase in WC $(7.2 \mathrm{~cm}, p<0.0001)$, W-HR $(0.8, p<0.0001)$, triceps skinfold thickness $(6.5 \mathrm{~mm} ; p<0.0001)$ 
and FBG $(3.5 \mathrm{mg} / \mathrm{dL}, p<0.04)$ was noted in girls, while a significant decrease was noted for HDL-c $(-4.6 \mathrm{mg} / \mathrm{dL}, p<0.0002)$ in boys [63].

Overall, there has been a general trend of increase of obesity in South Asia, including women and children [9-11,60-66]. Clearly, there is an urgent need for further epidemiological research using uniform criteria and standardized methodology for the diagnosis of obesity. Further, the studies should include populations from all regions and all sections of populations for generation of valid prevalence data from South Asian countries.

\section{Phenotype of Obesity in South Asians}

Various studies have shown that obesity phenotype differs according to ethnicity. In South Asians, several features of body composition are different from those seen in white Caucasians [9,20,27,67-72].

\subsection{Body Fat}

Several studies have shown that at similar level of BMI, body fat level is higher in Asians, particularly South Asians, as compared to white Caucasians [27,73-76]. This feature has been documented in other Asian ethnicities as well; Indonesians, Chinese, and Malays in Singapore $[20,67,68]$. In a study conducted in Singapore, at any given percentage of body fat, BMI value of Chinese, Malays and Asian Indians was $3 \mathrm{~kg} / \mathrm{m}^{2}$ lower than that in white Caucasians [67,68]. This can be partly explained by ethnicity, body frame (trunk-to-leg-length ratio and lean body), muscularity and adaptation to chronic calorie deprivation [77].

\subsection{Truncal and Abdominal Adiposity}

The truncal fat includes fat over chest and abdomen both subcutaneous abdominal adipose tissue (SCAT) and intra-abdominal adipose tissue (IAAT), all of which are more in Asian Indians than in white Caucasians $[9,27,75,76]$. The metabolic perturbations and adverse cardiovascular risk may be associated more with fat deposition in specific location over trunk and abdomen.

Migrant Asian Indians in USA had significantly greater total abdominal fat and IAAT than white Caucasians [74,75]. Further, truncal skin fold thicknesses are more in South Asians than in white Caucasians indicating more truncal SCAT [74,77-81] which could probably explain the higher prevalence of insulin resistance in a BMI and body fat-matched Asian Indian men as compared to white Caucasians in USA [79,81]. We have reported significant association of truncal skinfold thickness (signifying high truncal SCAT) with fasting hyperinsulinemia in Asian Indian children and adolescents as well [27]. Importantly, and contrary to results of studies on white Caucasians, SCAT was better correlated to the metabolic syndrome than IAAT in adult urban Asian Indians in multivariate analysis [82-90].

\section{Prediction Equations for Insulin Resistance and Body Fat Depots for Asian Indians}

Since it is not always possible to quantify insulin resistance, body fat, or body fat depots with the use of expensive and mostly hospital based measurement methods (e.g., hydro-densitometry and magnetic resonance imaging), we have developed predictive equations which use simple clinical 
measures. Models have been prepared using Classification and Regression Tree (CART) and multivariate regression for insulin resistance and body fat depots:

\subsection{For Insulin Resistance}

Three simple decision models have been developed based on routine clinical and biochemical parameters using CART and multivariate logistic regression to predict insulin resistance in apparently healthy Asian Indian adolescents [82-84]. Since costs of investigations are prohibitive at times in this region, anthropometric measurements, routine biochemical parameters, clinical parameters and gender have been used.

a. CART I, based on anthropometric parameters including $\sum 4 \mathrm{SF}$ (sum of biceps, triceps, subscapular and suprailiac skinfolds) and suprailiac skinfold thickness alone has sensitivity 88.2\%, specificity 50.1\% and area under Receiver Operating Characteristic curve (aROC) 77.8\%.

b. CART II, based on anthropometric and routine clinical and biochemical parameters (BMI, fasting plasma glucose levels and LDL-C) has sensitivity $94.5 \%$, specificity $38.3 \%$ and aROC $73.6 \%$.

c. CART III, based on all anthropometric, biochemical and clinical parameters, hip circumference ( $\mathrm{HC}$ in $\mathrm{cm})$; percentage body fat $(\% \mathrm{BF})$; ratio of sum of central (suprailiac and sub scapular) skinfolds to peripheral (biceps and triceps) skinfolds (C-P ratio); body fat mass (FM) in kg and LDL-C showed sensitivity $70.7 \%$, specificity $79.2 \%$ and aROC $77.4 \%$ [82-84].

\subsection{For Body Fat Depots}

The simplest equation for predicting \%BF derived from DEXA included age, sex, BMI, triceps skinfold and WC $\left(R^{2}=84.4 \%\right)$. Replacing BMI with weight and height reduced the overall variance $\left(R^{2}=86.4 \%\right)$.

Equations for prediction of total abdominal fat (TAF), IAAT and SCAT are listed in Table 3 [82-84].

Table 3. Predictive equations for estimation of various body fat depots in Asian Indians.

\begin{tabular}{l}
\hline \multicolumn{1}{c}{ Variable predictive equation } \\
\hline$\% \mathrm{BF}: 42.42+0.003 \times$ age $+7.04 \times$ gender $+0.42 \times \mathrm{TR}$ sf $+0.29 \times \mathrm{WC}+0.22 \times \mathrm{Wt}-0.42 \times \mathrm{Ht}$ \\
TAF: $-47,657.00+1384.11 \times$ gender $+1466.54 \times \mathrm{BMI}+416.10 \times \mathrm{WC}$ \\
IAAT: $-238.7+16.9 \times$ age $+934.18 \times$ gender $+578.09 \times \mathrm{BMI}-441.06 \times \mathrm{HC}+434.2 \times \mathrm{WC}$ \\
SCAT: $-49,376.4-17.15 \times$ age $+1016.5 \times$ gender $+783.3 \times \mathrm{BMI}+466 \times \mathrm{HC}$ \\
\hline
\end{tabular}

Notes: $\% B F, \%$ Body fat; gender: $\mathrm{M}=1, \mathrm{~F}=2$; TR sf, Triceps skinfold; WC, Waist circumference; Wt, Weight; Ht, Height; BMI, Body mass index; HC, Hip circumference; TAF, Total abdominal fat; IAAT, Intra-abdominal adipose tissue; SCAT, Subcutaneous abdominal adipose tissue; Adapted from [48].

\section{Deposition of Fat at "Ectopic" Sites}

Insulin sensitivity can be affected by fat accumulation in tissues other than where it is usually deposited ("ectopic fat"); for example, liver, muscle and heart. It appears that South Asians have tendency for deposition of fat in some of these sites [27]. 


\subsection{Hepatic Fat}

It is now recognized that NAFLD an important component of the metabolic syndrome [91,92]. Hepatic steatosis accompanied with portal inflammation in advanced stages is termed as non-alcoholic steato-hepatitis (NASH) and may progress to hepatic fibrosis and even cirrhosis.

It is estimated that approximately one fourth of the urban population in India has NAFLD [93-95]. In a case-control study, we showed that Asian Indians in north India with NAFLD have higher adiposity, fasting hyperinsulinemia, the metabolic syndrome and glucose intolerance than those without NAFLD [93]. Further, we studied hepatic gluconeogenesis pathway in non-diabetic Asian Indian males having NAFLD using in vivo $\left({ }^{31} \mathrm{P}\right)$ phosphorous magnetic resonance spectroscopy (MRS) and correlated it with anthropometry and surrogate marker of insulin resistance. Interestingly, non-obese non-diabetic subjects with NAFLD showed more derangements of hepatic gluconeogenesis enzymes than non-obese subjects without NAFLD [94]. In a comparative study in USA, South Asians had higher hepatic triglycerides levels, which were associated with lower adiponectin levels than white Caucasians [95-97]. It is possible, therefore, that Asian Indians have greater triglyceride deposition in liver than white Caucasians, which may be related to higher magnitude of insulin resistance or inherent genetic tendency.

\subsection{Skeletal Muscle Triglycerides}

Intra-myocellular lipids (IMCL) are located in the mitochondria, along with enzymes involved in fatty acid esterification, hydrolysis, ion transport and cellular oxidation. Combined effect of high concentration of serum insulin and free fatty acids can cause enhanced storage of IMCL. These lipids are believed to be important in the pathogenesis of insulin resistance and can be measured non-invasively using proton MRS [94,96,97]. We previously showed that excess IMCL deposition in soleus muscle was associated with abdominal obesity, but unlike in case of white Caucasians, the correlation with fasting insulin levels was not observed [98-100]. In a study by our group, the soleus muscle IMCL content and high sensitivity C-reactive protein (hs-CRP) levels were significantly higher in T2DM patients compared to healthy controls. However, values of insulin, other measures of insulin resistance, and hs-CRP levels did not correlate with soleus muscle IMCL content [98-100].

\subsection{Other Ectopic Sites of Fat Deposition}

There are few other ectopic sites of fat deposition; over the neck ("buffalo hump") frequently observed in Cushing's syndrome and HIV-associated lipodystrophy, and excess fat under the chin ("double chin") seen in familial partial lipodystrophy [101]. These ectopic fat depositions are frequently associated with insulin resistance and other features of the metabolic syndrome [101-103]. Extending research on these signs to obese people in whom these signs are frequently seen, we showed that mild "buffalo hump", and "double chin" signify the heightened risk of metabolic syndrome in urban Asian Indians [104]. 


\subsection{Adipocyte Size}

Large subcutaneous abdominal adipocyte size predicts insulin resistance and T2DM independent of obesity [105]. In this study, done on Pima Indians, mean subcutaneous abdominal adipocyte size was $19 \%$ and $11 \%$ higher in subjects with $\mathrm{T} 2 \mathrm{DM}$ and impaired glucose tolerance (IGT), respectively as compared to persons with normal glucose tolerance $(p<0.001)$ [105]. In this context, it is important to note that adipocyte cell size was significantly higher in South Asians $\left(3491 \pm 1393 \mu \mathrm{m}^{2}\right)$ as compared to white Caucasians in USA $\left(1648 \pm 864 \mu \mathrm{m}^{2} ; p\right.$-value $\left.=0.0001\right)$ [74]. These findings need to be further researched for clinical implications (Figure 1).

Figure 1. Comparative pictures of enlarged adipocytes from South Asian (left) and White (right) volunteers. Both images are obtained with SPOT digital camera using 10 magnification. Note: this figure is reproduced with permission from [74]. Copyright Chandalia et al., 2007.
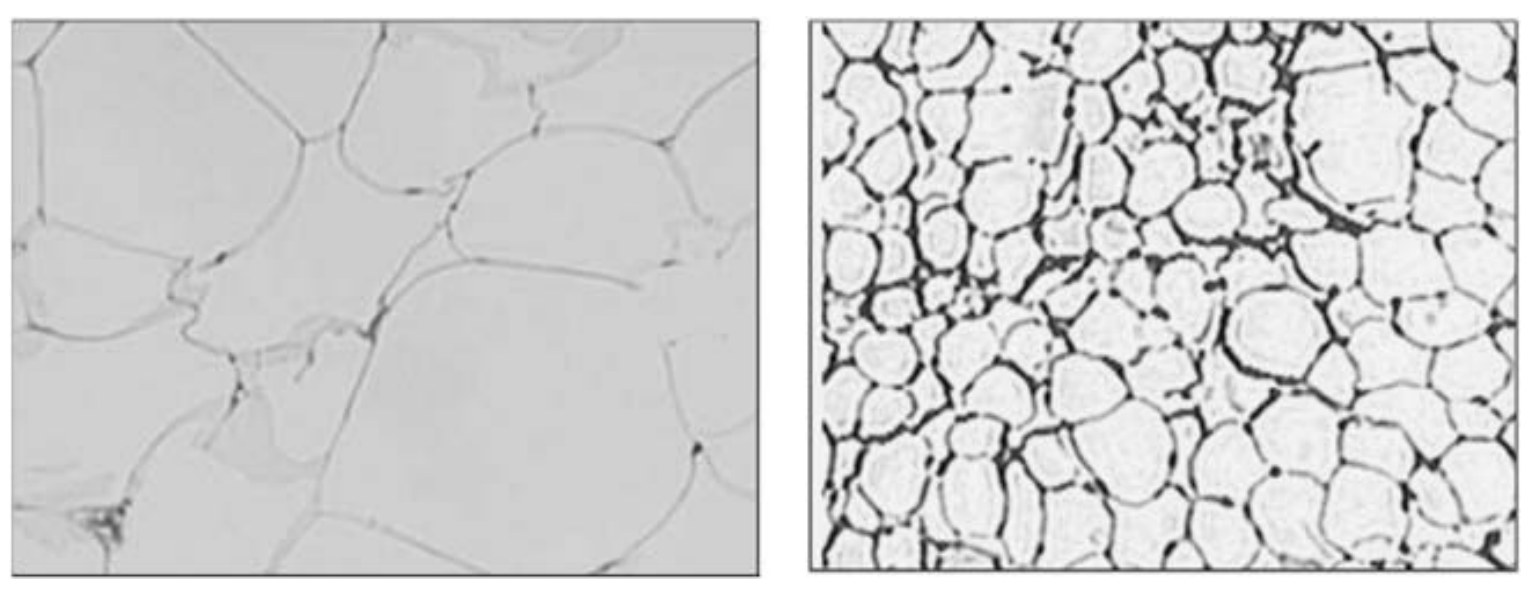

\section{Dyslipidemia}

Dyslipidemia signifies the increased concentration of total cholesterol and LDL cholesterol, decreased concentration of HDL cholesterol and hypertriglyceridemia present alone or in combination. A combination of lipid abnormalities, hypertriglyceridemia and low HDL, are metabolically interlinked and have been termed as "atherogenic dyslipidemia" [106,107]. This pattern of dyslipidemia has shown a strong association with T2DM and CVD in several studies in developed countries [107,108].

There is a paucity of studies on dyslipidemia in South Asians. The overall prevalence of dyslipidemia in India in various studies ranges from $10 \%$ to $73 \%$ [16], depending on area of residence (rural vs. urban), socio-economic stratum (high $v$ s. middle or low), diet and physical activity patterns and age. The prevalence of hypertriglyceridemia varied from $73 \%$ in obese and $61 \%$ in non-obese Asian Indians in urban areas and migrant Asians, the levels were relatively lower in rural areas but still higher than white Caucasians. The results from a recent cross-sectional study in urban New Delhi (north India) showed the prevalence of hypertriglyceridemia to be 42.7\% [48] (Table 4). In rural areas, the prevalence figures were lower than urban areas; however, recent data show increasing prevalence [36,54]. In particular, HDL levels are lower in South Asians than in White Caucasians as shown consistently in several comparative studies (Table 5). Importantly, the prevalence of 
atherogenic small, dense LDL was significantly higher in Asian Indians compared with white Caucasians in USA $(44 \%$ vs. $21 \% ; p<0.05)$ [109] and may contribute to increased tendency for CVD in this ethnic group. Finally, plasma concentration of adipose tissue metabolites, leptin and non-esterified fatty acids are higher and adiponectin levels are lower in insulin resistant Asian Indians as compared to more insulin sensitive Caucasians and could contribute to insulin resistance and atherogenic dyslipidemia [110,111].

Table 4. Prevalence of obesity and cardio-metabolic risk factors in urban population of New Delhi, India $(n=459)$.

\begin{tabular}{cc}
\hline Variable & Percentage \\
\hline Obesity (BMI criteria) & 50.1 \\
Impaired Fasting Glucose & 24 \\
Diabetes & 8.5 \\
Hypercholesterolemia & 26.6 \\
Hypertriglyceridemia & 42.7 \\
LDL-C $\geq 100 \mathrm{mg} / \mathrm{dL}$ & 51.6 \\
HDL-C $<40 \mathrm{mg} / \mathrm{dL}$ (males) & 37 \\
and $<50 \mathrm{mg} / \mathrm{dL}$ (females) & \\
\hline
\end{tabular}

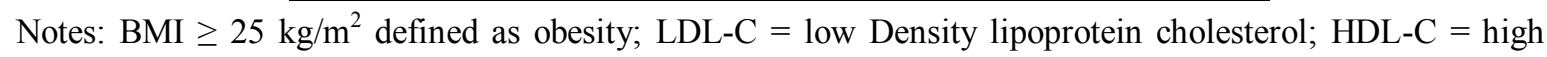
density lipoprotein cholesterol; Adapted from [48].

Table 5. Differences in the high-density lipoprotein cholesterol (HDL) levels between South Asians/Asian Indians vs. Whites/Europeans. Note: this table is reproduced with permission from [27]. Copyright The Endocrine Society, 2008.

\begin{tabular}{|c|c|c|c|c|}
\hline Author & $N$ & Parameter & $\begin{array}{c}\text { South Asians/Asian } \\
\text { Indians }\end{array}$ & Whites/Europeans \\
\hline \multicolumn{5}{|l|}{ Adults } \\
\hline Chandalia et al. [112] & 1031 AIs and 455 Whites $^{a}$ & $\begin{array}{l}\text { Percent population }{ }^{\mathrm{j}} \\
\text { with low HDL }\end{array}$ & $\begin{array}{c}\mathrm{M},\left(42 \%^{\mathrm{m}} ; 52 \%^{\mathrm{n}}\right) ; \\
\mathrm{F},\left(56 \%^{\mathrm{m}} ; 72 \%^{\mathrm{n}}\right)\end{array}$ & M, 35\%; F, 25\%* \\
\hline Ajjan et al. [113] & 245 SAs and 245 UK Whites & HDL (mmol/L) & 1.10 & $1.43 * *$ \\
\hline Williams et al. [114] & 63 SAs and 42 Europeans ${ }^{b}$ & $\mathrm{HDL}(\mathrm{mmol} / \mathrm{L})$ & 1.27 & 1.20 \\
\hline Smith et al. [115] & 82 AIs and 83 Caucasians $^{c}$ & $\mathrm{HDL}(\mathrm{mmol} / \mathrm{L})$ & $\mathrm{M}, 0.97 ; \mathrm{F}, 1.13$ & $\mathrm{M}, 1.24 ; \mathrm{F}, 1.51 *$ \\
\hline Somani et al. [116] & 141 SAs and 121 Whites & HDL (mmol/L) & 1.1 & 1.5 \\
\hline Bhalodkar et al. [117] & 119 AIs and 1752 Caucasians ${ }^{\mathrm{d}}$ & $\begin{array}{l}\mathrm{HDL}(\mathrm{mmol} / \mathrm{L}) \\
\mathrm{HDL} \operatorname{size}(\mathrm{nm})^{\mathrm{k}}\end{array}$ & 1.378 .9 & 1.379 .4 \\
\hline Forouhi et al. [118] & 113 SAs and Caucasians ${ }^{e}$ & $\mathrm{HDL}(\mathrm{mmol} / \mathrm{L})$ & $\mathrm{M}, 1.26, \mathrm{~F}, 1.51$ & $\mathrm{M}, 1.39 ; \mathrm{F}, 1.56$ \\
\hline Chambers et al. [119] & 518 AIs and 507 Whites ${ }^{f}$ & HDL (mmol/L) & 1.22 & $1.33 * *$ \\
\hline Enas et al. [120] & $\begin{array}{c}1131 \text { AI men and } 557 \text { AI women } \\
\text { compared with Caucasians } \\
\text { from FOS }\end{array}$ & $\mathrm{HDL}(\mathrm{mmol} / \mathrm{L})^{1}$ & M, 0.98; F, 1.24 & $\begin{array}{l}\mathrm{M}, 1.18 * * \\
\mathrm{~F}, 1.45 * *\end{array}$ \\
\hline McKeigue et al. [121] & 1421 SAs and 1515 Europeans ${ }^{\text {h }}$ & $\mathrm{HDL}(\mathrm{mmol} / \mathrm{L})$ & 1.16 & 1.25 \\
\hline \multirow{2}{*}{ McKeigue et al. [122] } & \multirow{2}{*}{253 Bangladeshis and Europeans ${ }^{i}$} & $\mathrm{HDL}(\mathrm{mmol} / \mathrm{L})$ & M, 1.13; F, 1.19 & $\mathrm{M}, 1.43 ; \mathrm{F}, 1.45$ \\
\hline & & Percent of TC as HDL (\%) & M, 21.3; F, 22.4 & $\mathrm{M}, 25.3 ; \mathrm{F}, 25.2$ \\
\hline
\end{tabular}


Table 5. Cont.

\begin{tabular}{|c|c|c|c|c|}
\hline Children & & & & \\
\hline Ehtisham et al. [123] & $\begin{array}{l}65 \text { SAs and } 64 \text { European } \\
\text { adolescents (14-17 years) }\end{array}$ & $\mathrm{HDL}(\mathrm{mmol} / \mathrm{L})$ & M, 1.28; F, 1.49 & $\mathrm{M}, 1.39 ; \mathrm{F}, 1.67$ \\
\hline Whincup et al. [124] & $\begin{array}{c}73 \text { SAs and } 1287 \text { Caucasian } \\
\text { children (10-11 years) }\end{array}$ & $\mathrm{HDL}(\mathrm{mmol} / \mathrm{L})$ & 1.38 & 1.43 \\
\hline
\end{tabular}

Notes: AI, Asian Indian; BMI, body mass index; CURES, The Chennai Urban Rural Epidemiology Study; F, female; FOS, Framingham Offspring Study; HDL, high-density lipoprotein cholesterol; M, male; $N$, number of sample population; SA; South Asians; TC, total cholesterol; UK, United Kingdom; ${ }^{a}$ Indigenous Asian Indians from CURES study; ${ }^{\mathrm{b}}$ Men aged 35-75 years; ${ }^{\mathrm{c}}$ Aged 20-60 years; ${ }^{\mathrm{d}}$ Women from the Framingham Offspring Study; ${ }^{\mathrm{e}}$ BMI matched, aged 40-55 years; ${ }^{\mathrm{f}}$ Aged 35-60 years; ${ }^{\mathrm{g}}$ Women from the Framingham Offspring Study; ${ }^{\mathrm{h}}$ Males; ${ }^{\mathrm{i}}$ Aged 35-69 years; ${ }^{\mathrm{j}}$ Low HDL: males $<1.036 \mathrm{mmol} / \mathrm{L}$ and females $<1.295 \mathrm{mmol} / \mathrm{L} ;{ }^{k}$ HDL particle size in nanometers; ${ }^{1}$ Men aged 30-39 years, and women aged 30-59 years; ${ }^{\mathrm{m}}$ Urban; ${ }^{\mathrm{n}}$ Rural; * $p<0.0001 ; * * p<0.001$.

\section{Determinants of Obesity and Dyslipidemia in South Asians}

\subsection{Nutritional Transition}

South Asians are becoming increasingly more affluent. Further, with economic liberalization, there is a widespread presence of transnational food company outlets and availability of packaged foods in $24 \mathrm{~h}$ supermarkets. With better purchasing power, South Asians are increasingly consuming diets high in saturated fats, cholesterol, and refined carbohydrates and low in polyunsaturated fatty acids and fiber [51]. Availability of edible vegetable oils for consumption has nearly tripled in developing countries in the last few years. Importantly, while processed non-traditional "fast-foods" contribute to faulty diets, some of the locally made "fast foods" sold by street vendors in several developing countries are equally unhealthy. These food items contain high amount of trans fatty acids (TFA) due to deep-frying using low cost and widely available partially hydrogenated vegetable oils $[51,125]$.

\subsection{Urbanization, Demographic Transition and Rural-to-Urban Migration}

In South Asia, urbanization is increasing rapidly and is now nearly $38 \%$, but is expected to be $50 \%$ by 2020 [126]. Urbanization exposes people to a number of challenges, imbalanced diets, physical inactivity, long working hours and other urban stress making them vulnerable to NCDs. The average life expectancy of Indian population at birth now is 67.14 years, as compared to 31 years in 1947 [127]. Similarly, life expectancy is going up in the other countries of the region as well. This has resulted in the rise of elderly population in the region, again leading to rise in NCDs.

Migration, whether inter-country or rural-to-urban within country, is a risk factor for T2DM. In a review, South Asian migrants showed nearly four times high prevalence rates of T2DM than those of rural sedentee populations. Similar observations were also reported in intra-country migrants and resettled indigenous populations [128]. Migration results in increasing physical inactivity, faulty nutrition and exposure to stress. We have previously shown that migrant postmenopausal women settled in urban slums have high prevalence of multiple CVD risk factors [10]. In a recent study, we have shown a gradient in NCDs between rural, rural-urban migrants and urban residents [49]. 
Importantly, there was a significant correlation of duration of migration with waist size and high fat content in the diets $(p<0.001)$ (Figure 2).

Figure 2. Age-adjusted ORs and 95\% CIs for prevalence of cardiovascular risk factors in different groups of women (rural-urban, urban and urban-rural migrants) as compared with the rural women, high prevalence of high waist circumference $\geq 80 \mathrm{~cm}$, and hypercholesterolemia $\geq 200 \mathrm{mg} / \mathrm{dL}$ among rural-urban migrants and urban women. The prevalence declines among the urban-rural migrants. Note: this figure is reproduced with permission from [49]. Copyright the BMJ Publishing Group Ltd., 2011.
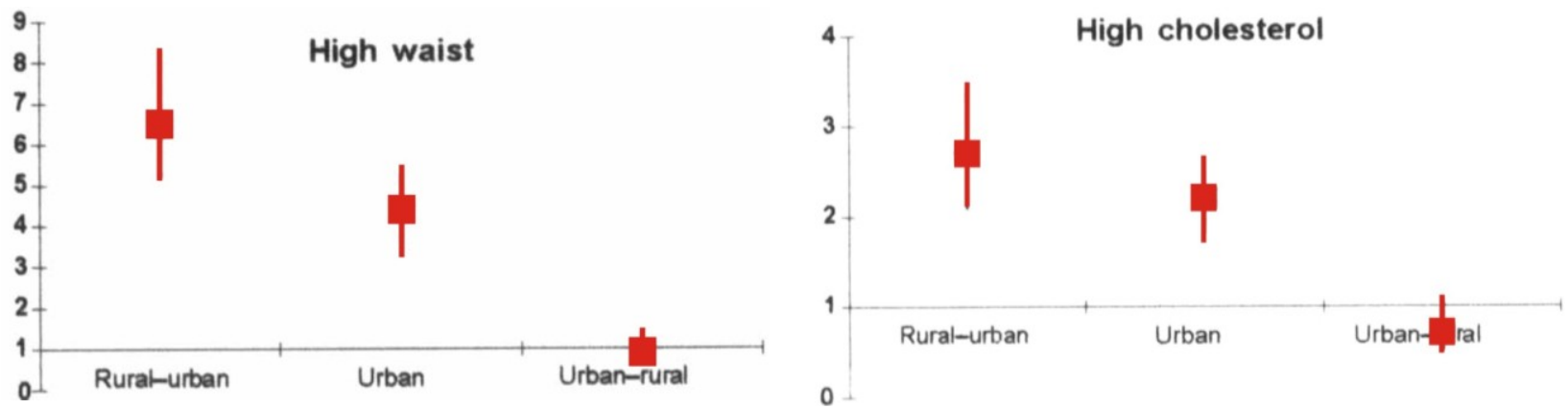

\subsection{Physical Inactivity}

Sedentary life style compounded with the change in the nutritional pattern in South Asians makes them more vulnerable to NCDs [27]. The changes of occupations, advent of newer technologies, and rapid pace of urban life have increasingly resulted in more sedentary work and less energy expenditure; however, this needs more research in context of South Asians. In one such study, lower levels of physical activity in Asian Indians, Pakistanis and Bangladeshis was seen to be inversely correlated with BMI, WC, systolic blood pressure, plasma glucose and insulin levels [27,129]. Determinants of physical inactivity in South Asians have not been systematically studied.

\subsection{Socio-Economic and Cultural Factors}

The prevalence of obesity, dyslipidemia, T2DM and CVD in South Asia is more in the people belonging to the upper socio-economic strata unlike in the developed nations [9,27]. However, with new found wealth and a number of dietary choices and "western foods" available at relatively low prices, people belonging to middle and low socio-economic strata are being increasingly afflicted with NCDs [27,62].

Socio-cultural and psychological factors and prevalent misconceptions are important in modifying diet and lifestyle habits of women and children in South Asia. In this region, there is a prevalent misconception that an "obese child is a healthy child" and, hence should be fed in excess. Mothers often have traditional belief that feeding excess ghee (clarified butter) and butter to child would be beneficial to growth and impart them strength. In a cross-sectional study of 1800 children aged 9 to 18 years and their mothers, using qualitative (focus group) and quantitative (semi-structured survey) data, widely prevalent myths, and correlation between obesity and dietary habits of children and their mothers has been shown [130]. Other social factors as a cause of physical inactivity are: priority for 
academics at the cost of playing time in children, increasing use of television and computers, lack of playfields and open spaces, and security concerns in the outdoors, especially for women $[60,61,66]$. In particular, cultural and social restrictions for outdoor physical activity in women in South Asian countries may be an important reason for increasing obesity and the metabolic syndrome.

\subsection{Genetics}

A few studies show genetic association of obesity, insulin resistance and dyslipidemia in South Asians (Figure 3). In a recent study, variants of Myostatin gene was shown to predispose to obesity, abdominal obesity and low lean body mass in Asian Indians in north India [131]. In another important study, LMNA 1908T/T and C/T genotypes emerged as independent genetic risk factors for generalized obesity in non-diabetic Asian Indians in north India [132]. Association of AMD1 variant with obesity has been shown in Asian Indian children [133]. Further, there is recent evidence for genetic associations of NAFLD with SREBP-2 $1784 \mathrm{G}>\mathrm{C}$ genotype [134] and peroxisome proliferator activated receptor- $\gamma$ (Pro12Ala and C161T) polymorphisms [135] in Asian Indians. A recent study has shown DOK5 as a susceptibility gene for obesity and T2DM in Asian Indians in north India [136]. Finally, genetic susceptibility of Asian Indians to development of dyslipidemia has been shown in some studies [131-133,136-139].

Figure 3. Complex interactions of genetic, perinatal, nutritional and other acquired factors in development of insulin resistance, type-2 diabetes and coronary heart disease in South Asians. T2DM, type 2 diabetes mellitus; CRP, C-reactive protein; CHD coronary heart disease. Adapted from [9].

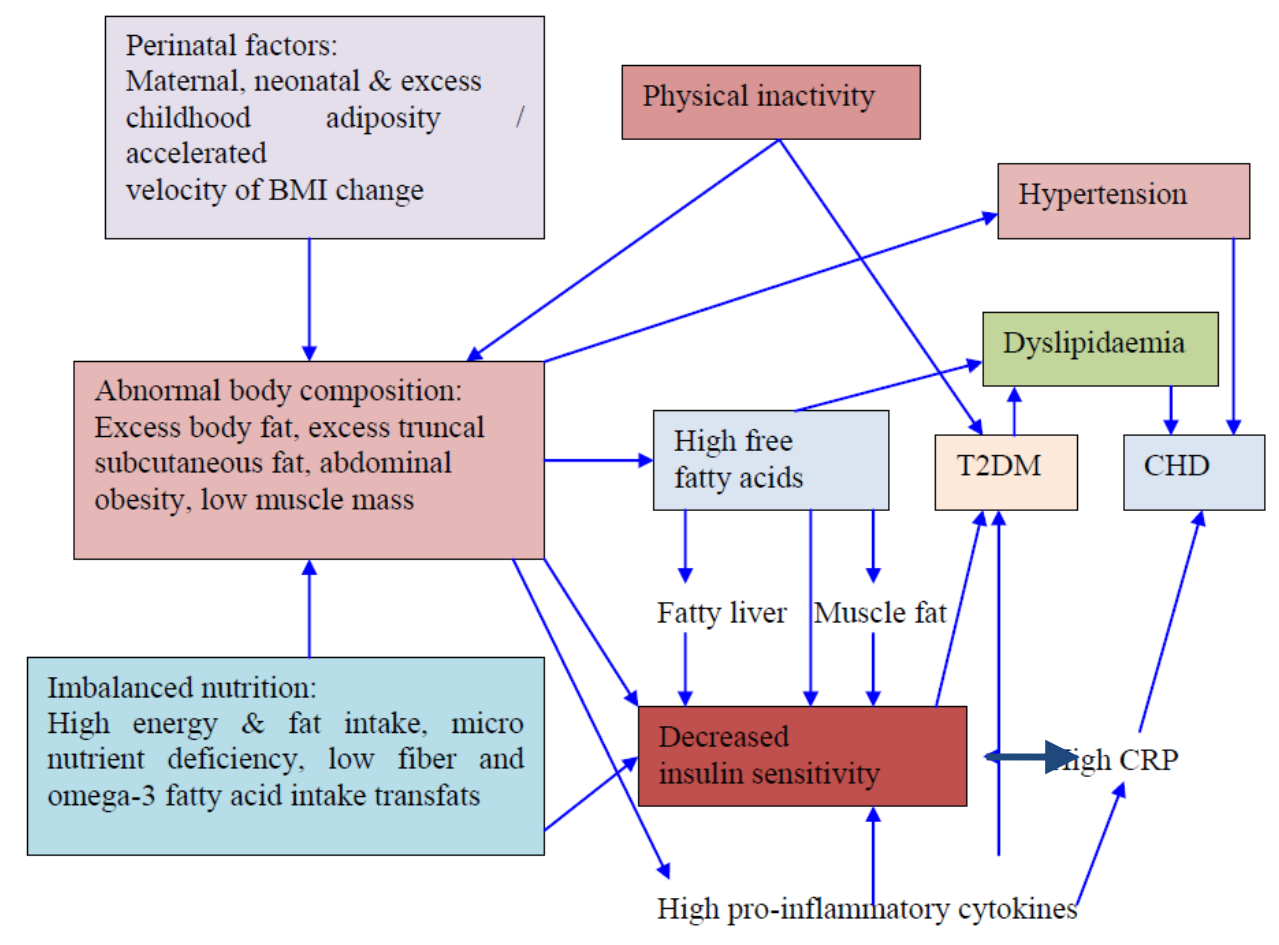




\section{Interventions}

Low awareness regarding modifiable risk factors (diet and physical activity) in South Asians should be addressed in a comprehensive and culturally specific manner [140,141]. In this context, it is important to note that Consensus Dietary Guidelines have been developed for Asian Indians for prevention of obesity and T2DM and include reduction in the intake of carbohydrates, preferential intake of complex carbohydrates and low glycemic index foods, higher intake of fiber, lower intake of saturated fats, optimal ratio of essential fatty acids, reduction in trans fatty acids, low intake of salt and restricted intake of sugar [140]. Other document, which is important to formulate interventions, includes the Consensus Physical Activity Guidelines for Indians, where more intensive physical activity, a total of $60 \mathrm{~min}$ of physical activity every day, is recommended for Asian Indians. This should include at least 30 min of moderate-intensity aerobic activity, 15 min of work-related activity, and 15 min of muscle-strengthening exercises [141].

There is a paucity of well-designed intervention studies for prevention of NCDs in South Asians. The available data have been reviewed below.

\subsection{Adults}

An intervention study for prevention of T2DM, conducted in Tamilnadu (south India] on 531 males and females aged 35-55 years with impaired glucose tolerance, was designed to test lifestyle intervention compared to metformin. This study showed $28.5 \%$ reduction of incident cases of diabetes with lifestyle intervention, $26.4 \%$ with metformin and $28.2 \%$ with a combination of both as compared to the control group. Besides reiterating that lifestyle interventions are still the best for prevention of diabetes in Asian Indians, this intervention trial has demonstrated that both lifestyle and metformin interventions are cost effective strategies for prevention of diabetes in resource-constrained South Asian countries [142,143].

\subsection{School Children}

An intervention program entitled, "Medical education for children/Adolescents for Realistic prevention of obesity and diabetes and for healthy aGeing (MARG; Hindi for "path") conducted in three large cities of North India (New Delhi, Agra and Jaipur) resulted in novel research data in schoolchildren residing in India. A sub study, in which the knowledge and practices (KAPs) of children regarding health, nutrition and NCDs on 2500 children were assessed, these parameters were shown to be significantly improved in the post-intervention phase, particularly in 8-11 years old as compared to their elder counterparts (12-18 years). Similarly, significantly higher improvement of KAPs was recorded in children studying in government schools (catering to low socio-economic stratum) as compared to private schools (catering to high and middle socio-economic strata) [144]. In another sub-study, 15-17 years old children were researched in two randomly allocated schools (intensive education and counseling in one school vs. usual education and counseling in the second school). After 6 months of intervention, we observed better lifestyle practices (less TV viewing and eating more fruits), a significant decrease in waist hip ratio, better insulin sensitivity, and significantly 
lower hs-CRP values in the intervention group vs. control group [144-147]. These data provide locally and culturally specific modules for successful intervention in South Asians at an early age.

\section{Conclusions}

South Asians are facing growing "epidemics" of obesity and dyslipidemia. Several factors including rapid urbanization, demographic changes, rural-to-urban migration, faulty diets, sedentary lifestyle, socio-cultural factors alongwith genetic predisposition have emerged as major contributory factors. Obesity in south Asians showed certain distinct features including preponderance of abdominal obesity, more intra-abdominal and truncal sub-cutaneous adiposity, fat deposition in liver (fatty liver) and skeletal muscles. Different and lower cut offs for BMI and waist circumference, and specific guidelines for diet and physical activity have been advocated for Asian Indians. Evidence is available for effective intervention programs with emphasis on nutrition, physical activity and life style changes in children, and also in adults for prevention of obesity, T2DM and dyslipidemia.

\section{Conflict of Interest}

The authors declare no conflict of interest.

\section{References}

1. Bloom, D.E.; Rosenberg, L. The Future of South Asia: Population Dynamics, Economic Prospects, and Regional Coherence. Available online: http://www.hsph.harvard.edu/pgda/ WorkingPapers/2011/PGDA_WP_68.pdf(accessed on 12 January 2013).

2. The Growing Danger of Non Communicable Diseases: Acting Now to Reverse Course. Available online: http://siteresources.worldbank.org/HEALTHNUTRITIONANDPOPULATION/ Resources/Peer-Reviewed-Publications/WBDeepeningCrisis.pdf (accessed on 24 April 2012).

3. Nikolic, I.A.; Stanciole, A.E.; Zaydman, M. Chronic Emergency: Why NCDs Matter. Available online: http://siteresources.worldbank.org/HEALTHNUTRITIONANDPOPULATION/Resources/ 281627-1095698140167/ChronicEmergencyWhyNCDsMatter.pdf (accessed on 2 September 2011).

4. Key Facts. Obesity and Overweight. Available online: http://www.who.int/mediacentre/ factsheets/fs311/en/index.html (accessed on 26 January 2013).

5. Global Status Report on Non-communicable Diseases 2010. Available online: http://www.who.int/nmh/publications/ncd_report2010/en/(accessed on 26 July 2012).

6. De Onis, M.; Blössner, M.; Borghi, E. Global prevalence and trends of overweight and obesity among preschool children. Am. J. Clin. Nutr. 2010, 92, 1257-1264.

7. Mathers, C.D.; Loncar, D. Projections of global mortality and burden of disease from 2002 to 2030. PLoS Med. 2006, 3, e442.

8. Engelgau, M.; El-Saharty, S.; Kudesia, P.; Rajan, V.; Rosenhouse, S.; Okamoto, K. Capitalizing on the Demographic Transition: Tackling Non-Communicable Diseases in South Asia; World Bank: Washington, DC, USA, 2011.

9. Misra, A.; Khurana, L. Obesity and the metabolic syndrome in developing countries. J. Clin. Endocrinol. Metab. 2008, 93, S9-S30. 
10. Misra, A.; Pandey, R.M.; Devi, J.R.; Sharma, R.; Vikram, N.K.; Khanna, N. High prevalence of diabetes, obesity and dyslipidaemia in urban slum population in northern India. Int. J. Obes. Relat. Metab. Disord. 2001, 25, 1722-1729.

11. Wasir, J.S.; Misra, A. The metabolic syndrome in Asian Indians: The impact of nutritional and socio-economic transition in India. Met. Syndr. Relat. Disord. 2004, 2, 14-23.

12. Misra, A.; Vikram, N.K. Insulin resistance syndrome (metabolic syndrome) and obesity in Asian Indians: Evidence and implications. Nutrition 2004, 20, 482-491.

13. Misra, A.; Sharma, R.; Pandey, R.M.; Khanna, N. Adverse profile of dietary nutrients, anthropometry and lipids in urban slum dwellers of northern India. Eur. J. Clin. Nutr. 2001, 55, $727-734$.

14. Smith, D.G. Epidemiology of dyslipidemia and economic burden on the health care system. Am. J. Manag. Care 2007, 13, S68-S71.

15. Goff, D.C.; Betoni, A.G.; Kramer, H.; Bonds, D.; Blumenthal, R.S.; Tsai, M.Y.; Psatsy, B.M. Dyslipidemia prevalence, treatment, and control in the multi-Ethnic study of atherosclerosis (MESA) gender, ethnicity, and coronary artery calcium. Circulation 2006, 113, 647-656.

16. Misra, A.; Luthra, K.; Vikram, N.K. Dyslipidemia in Asian Indians: Determinants and significance. J. Assoc. Physicians India 2004, 52, 137-142.

17. Office of the Registrar General \& Census Commissioner, India. Available online: www.censusindia.gov.in (accessed on 30 April 2013).

18. WHO Expert Consultation. Appropriate body-mass index for Asian populations and its implications for policy and intervention strategies. Lancet 2004, 363, 157-163.

19. Gupta, R.; Sarna, M.; Thanvi, J.; Rastogi, P.; Kaul, V.; Gupta, V.P. High prevalence of multiple coronary risk factors in Punjabi Bhatia community. Jaipur Heart Watch-3. Indian Heart J. 2004, $56,646-652$.

20. Deurenberg, P.; Yap, M.; van Staveren, W.A. Body mass index and percent body fat: A meta analysis among different ethnic groups. Int. J. Obes. Relat. Metab. Disord. 1998, 22, 1164-1171.

21. Deurenberg-Yap, M.; Chew, S.K.; Lin, V.F.; Tan, B.Y.; van Staveren, W.A.; Deurenberg, P. Relationships between indices of obesity and its co-morbidities in multi-ethnic Singapore. Int. J. Obes. Relat. Metab. Disord. 2001, 25, 1554-1562.

22. Vikram, N.K.; Pandey, R.M.; Misra, A.; Sharma, R.; Devi, J.R.; Khanna, N. Non-obese (body mass index $<25 \mathrm{~kg} / \mathrm{m}^{2}$ ) Asian Indians with normal waist circumference have high cardiovascular risk. Nutrition 2003, 19, 503-509.

23. Misra, A. We Need Ethnic-Specific Criteria for Classification of BMI. In Progress in Obesity Research; Medeiros-Neto, G., Halpern, A., Bouchrad, C., Eds.; John Libbey Eurotext Ltd.: London, UK, 2003; pp. 547-553.

24. Misra, A. Revision of limits of body mass index to define overweight and obesity are needed for the Asian ethnic groups. Int. J. Obes. Relat. Metab. Disord. 2003, 27, 1294-1296.

25. Stevens, J. Ethnic-specific cut points for obesity vs country-specific guidelines for action. Int. J. Obes. Relat. Metab. Disord. 2003, 27, 287-288.

26. Asia-Pacific Steering Committee. The Asia-Pacific Perspective: Redefining Obesity and Its Treatment; International Diabetes Institute; Health Communications Australia: St Leonards, Australia, 2000. 
27. Misra, A.; Khurana, L. Obesity related non-communicable diseases: South Asians vs White Caucasians. Int. J. Obes. 2011, 35, 167-187.

28. Misra, A.; Chowbey, P.K.; Makkar, B.M.; Vikram, N.K.; Wasir, J.S.; Chadha, D.; Joshi, S.R.; Sadikot, S.; Gulati, S.; Munjal, Y.P. Consensus statement for diagnosis of obesity, abdominal obesity and the metabolic syndrome for Asian Indians and recommendations for physical activity, medical and surgical management. J. Assoc. Physicians India 2009, 57, 163-170.

29. Grundy, S.M.; Brewer, H.B., Jr.; Cleeman, J.I.; Smith, S.C., Jr.; Lenfant, C. Definition of metabolic syndrome: Report of the National Heart, Lung, and Blood Institute/American Heart Association conference on scientific issues related to definition. Circulation 2004, 109, 433-438.

30. Grundy, S.M.; Cleeman, J.I.; Daniels, S.R.; Donato, K.A.; Eckel, R.H.; Franklin, B.A.; Gordon, D.J.; Krauss, R.M.; Savage, P.J.; Smith, S.C., Jr.; et al. Diagnosis and management of the metabolic syndrome. An American Heart Association/National Heart, Lung, and Blood Institute Scientific Statement. Executive Summary. Circulation 2005, 112, 2735-2752.

31. Einhorn, D.; Reaven, G.M.; Cobin, R.H.; Ford, E.; Ganda, O.P.; Handelsman, Y.; Hellman, R.; Jellinger, P.S.; Kendall, D.; Krauss, R.M.; et al. American College of Endocrinology position statement on the insulin resistance syndrome. Endocr. Pract. 2003, 9, 237-252.

32. How Do We Define Obesity and Overweight? Obesity and Overweight. Available online: http://www.who.int/dietphysicalactivity/media/en/gsfs_obesity.pdf (accessed on 6 May 2013).

33. IDF Worldwide Definition of the Metabolic Syndrome. Available online: http://www.idf.org/ metabolic-syndrome (accessed on 29 November 2012).

34. National Cholesterol Education Program (NCEP) Expert Panel on Detection, Evaluation, and Treatment of High Blood Cholesterol in Adults (Adult Treatment Panel III). Third Report of the National Cholesterol Education Program (NCEP) Expert Panel on Detection, Evaluation, and Treatment of High Blood Cholesterol in Adults (Adult Treatment Panel III) final report. Circulation 2002, 106, 3143-3421.

35. Dhurandhar, N.V.; Kulkarni, P.R. Prevalence of obesity in Bombay. Int. J. Obes. Relat. Metab. Disord. 1992, 16, 367-375.

36. Gupta, A.; Gupta, R.; Sarna, M.; Rastogi, S.; Gupta, V.P.; Kothari, K. Prevalence of diabetes, impaired fasting glucose and insulin resistance syndrome in an urban Indian population. Diabetes Res. Clin. Pract. 2003, 61, 69-76.

37. Gupta, R.; Deedwania, P.C.; Gupta, A.; Rastogi, S.; Panwar, R.B.; Kothari, K. Prevalence of metabolic syndrome in an Indian urban population. Int. J. Cardiol. 2004, 97, 257-261.

38. Prabhakaran, D.; Shah, P.; Chaturvedi, V.; Ramakrishnan, L.; Manhapra, A.; Reddy, K.S. Cardiovascular risk factor prevalence among men in a large industry of northern India. Natl. Med. J. India 2005, 18, 59-65.

39. Misra, A.; Wasir, J.S.; Pandey, R.M. An evaluation of candidate definitions of the metabolic syndrome in adult Asian Indians. Diabetes Care 2005, 28, 398-403.

40. Gupta, R.; Sarna, M.; Thanvi, J.; Sharma, V.; Gupta, V.P. Fasting glucose and cardiovascular risk factors in an urban population. J. Assoc. Physicians India 2007, 55, 705-709.

41. Deepa, M.; Farooq, S.; Deepa, R.; Manjula, D.; Mohan, V. Prevalence and significance of generalized and central body obesity in an urban Asian Indian population in Chennai, India (CURES: 47). Eur. J. Clin. Nutr. 2009, 63, 259-267. 
42. Wijewardene, K.; Mohideen, M.R.; Mendis, S.; Fernando, D.S.; Kulathilaka, T.; Weerasekara, D.; Uluwitta, P. Prevalence of hypertension, diabetes and obesity: Baseline findings of a population based survey in four provinces in Sri Lanka. Ceylon Med. J. 2005, 50, 62-70.

43. Zaman, M.M.; Yoshiike, N.; Rouf, M.A.; Syeed, M.H.; Khan, M.R.; Haque, S.; Mahtab, H.; Tanaka, H. Cardiovascular risk factors: Distribution and prevalence in a rural population of Bangladesh. J. Cardiovasc. Risk 2001, 8, 103-108.

44. Nanan, D. Health status of the Pakistani population. Am. J. Public Health 2001, 91, 1545-1546.

45. Vaidya, A.; Pokharel, P.K.; Nagesh, S.; Karki, P.; Kumar, S.; Majhi, S. Association of obesity and physical activity in adult males of Dharan, Nepal. Kathmandu Univ. Med. J. 2006, 4, 192-197.

46. WHO STEPS Surveillance. Non-Communicable Disease Risk Factor Survey 2008; Ministry of Health and Population: Kathmandu, Nepal, 2008.

47. Chow, C.K.; Naidu, S.; Raju, K.; Raju, R.; Joshi, R.; Sullivan, D.; Celermajer, D.S.; Neal, B.C. Significant lipid, adiposity and metabolic abnormalities amongst 4535 Indians from a developing region of rural Andhra Pradesh. Atherosclerosis 2008, 196, 943-952.

48. Bhardwaj, S.; Misra, A.; Misra, R.; Goel, K.; Bhatt, S.P.; Rastogi, K.; Vikram, N.K.; Gulati, S. High prevalence of abdominal, intra-abdominal and subcutaneous adiposity and clustering of risk factors among urban Asian Indians in North India. PLoS One 2011, 6, e24362.

49. Gupta, R.; Agrawal, A.; Misra, A.; Gupta, S.; Pandey, R.M.; Misra, P.; Vikram, N.K.; Dey, S.; Rao, S.; Menon, V.U.; et al. Migrating husbands and changing cardiovascular risk factors in the wife: A cross sectional study in Asian Indian women. J. Epidemiol. Community Health 2012, 66, 881-889.

50. Popkin, B.M.; Adair, L.S.; Ng, S.W. Global nutrition transition and the pandemic of obesity in developing countries. Nutr. Rev. 2012, 70, 3-21.

51. Misra, A.; Khurana, L.; Isharwal, S.; Bhardwaj, S. South Asian diets and insulin resistance. Br. J. Nutr. 2009, 101, 465-473.

52. Chadha, S.L.; Gopinath, N.; Shekhawat, S. Urban-rural differences in the prevalence of coronary heart disease and its risk factors in Delhi. Bull. World Health Organ. 1997, 75, 31-38.

53. Kaur, P.; Rao, S.R.; Radhakrishnan, E.; Rajasekar, D.; Gupte, M.D. Prevalence, awareness, treatment, control and risk factors for hypertension in a rural population in South India. Int. J. Public Health 2012, 57, 87-94.

54. Misra, P.; Upadhyay, R.P.; Krishnan, A.; Vikram, N.K.; Sinha, S. A community-based study of metabolic syndrome and its components among women of rural community in Ballabgarh, Haryana. Met. Syn. Relat. Disord. 2011, 10, 1-8.

55. Misra, R.; Misra, A.; Vikram, N.K.; Gupta, N.S.; Sharma, S.S.; Patel, S.; Thakor, B.P. Difference in prevalence of diabetes, obesity, metabolic syndrome and associated cardiovascular risk factors in a rural area of Tamil Nadu and an urban area of Delhi. Int. J. Diabetes Dev. Ctries. 2011, 31, 82-90.

56. Misra, A.; Vikram, N.K. Clinical and patho-physiological consequences of abdominal adiposity and abdominal adipose tissue depots. Nutrition 2003, 19, 457-466.

57. India. National Family Health Survey (NFHS-2). Key Findings. Available online: www.measuredhs.com/pubs/pdf/SR81/SR81.pdf (accessed on 14 May 2012). 
58. India. National Family Health Survey (NFHS-3). 2005-06. Key Findings. Available online: www.measuredhs.com/pubs/pdf/SR128/SR128.pdf (accessed on 4 May 2013).

59. Bharati, S.; Pal, M.; Bhattacharya, B.N.; Bharati, P. Prevalence and causes of chronic energy deficiency and obesity in Indian women. Hum. Biol. 2007, 79, 395-412.

60. Bhardwaj, S.; Misra, A.; Khurana, L.; Gulati, S.; Shah, P.; Vikram, N.K. Childhood obesity in Asian Indians: A burgeoning cause of insulin resistance, diabetes and sub-clinical inflammation. Asia Pac. J. Clin. Nutr. 2008, 17, 172-175.

61. Misra, A.; Vikram, N.K.; Arya, S.; Pandey, R.M.; Dhingra, V.; Chatterjee, A.; Dwivedi, M.; Sharma, R.; Luthra, K.; Guleria, R.; Talwar, K.K. High prevalence of insulin resistance in post-pubertal Asian Indian children is associated with adverse truncal body fat patterning, abdominal adiposity and excess body fat. Int. J. Obes. Relat. Metab. Disord. 2004, 28, $1217-1226$.

62. Misra, A.; Khurana, L.; Vikram, N.K.; Goel, A.; Wasir, J.S. Metabolic syndrome in children: Current issues and South Asian perspective. Nutrition 2007, 23, 895-910.

63. Singhal, N.; Misra, A.; Shah, P.; Rastogi, K.; Vikram, N.K. Secular trends in obesity, regional adiposity and metabolic parameters among Asian Indian adolescents in North India: A comparative data analysis of two selective samples 5 years apart $(2003,2008)$ Ann. Nutr. Metab. 2010, 56, 176-181.

64. Misra, A.; Madhavan, M.; Vikram, N.K.; Pandey, R.M.; Dhingra, V.; Luthra, K. Simple anthropometric measures identify fasting hyperinsulinemia and clustering of cardiovascular risk factors in Asian Indian adolescents. Metabolism 2006, 55, 1569-1573.

65. Raj, M.; Sundaram, K.R.; Paul, M.; Deepa, A.S.; Kumar, R.K. Obesity in Indian children: Time trends and relationship with hypertension. Natl. Med. J. India 2007, 20, 288-293.

66. Misra, A.; Shah, P.; Goel, K.; Hazra, D.K.; Gupta, R.; Seth, P.; Tallikoti, P.; Mohan, I.; Bhargava, R.; Bajaj, S.; et al. The high burden of obesity and abdominal obesity in Urban Indian school children: A multi-centric study of 38,296 children. Ann. Nutr. Metab. 2011, 58, 203-211.

67. Deurenberg-Yap, M.; Schmidt, G.; van Staveren, W.A.; Deurenberg, P. The paradox of low body mass index and high body fat percentage among Chinese, Malays and Indians in Singapore. Int. J. Obes. Relat. Metab. Disord. 2000, 24, 1011-1017.

68. Deurenberg-Yap, M.; Schmidt, G.; van Staveren, W.A.; Hautvast, J.G.; Deurenberg, P. Body fat measurement among Singaporean Chinese, Malays and Indians: A comparative study using a four-compartment model and different two-compartment models. Br. J. Nutr. 2001, 85, 491-498.

69. Banerji, M.A.; Faridi, N.; Alturi, R.; Chaiken, R.L.; Lebovitz, H.E. Body composition, visceral fat, leptin and insulin resistance in Asian Indian men. J. Clin. Endocrinol. Metab. 1999, 84, 137-144.

70. Dudeja, V.; Misra, A.; Pandey, R.M.; Devina, G.; Kumar, G.; Vikram, N.K. BMI does not accurately predict overweight in Asian Indians in northern India. Br. J. Nutr. 2001, 86, 105-112.

71. Misra, A.; Athiko, D.; Sharma, R.; Pandey, R.M.; Khanna, N. Non-obese hyperlipidemic Asian northern Indian males have adverse anthropometric profile. Nutr. Metab. Cardiovasc. Dis. 2002, $12,178-183$. 
72. Chandalia, M.; Abate, N.; Garg, A.; Stray-Gundersen, J.; Grundy, S.M. Relationship between generalized and upper body obesity to insulin resistance in Asian Indian men. J. Clin. Endocrinol. Metab. 1999, 84, 2329-2335.

73. Misra, A.; Vikram, N.K.; Gupta, R.; Pandey, R.M.; Wasir, J.S.; Gupta, V.P. Waist circumference cutoff points and action levels for Asian Indians for identification of abdominal obesity. Int. J. Obes. 2006, 30, 106-111.

74. Chandalia, M.; Lin, P.; Seenivasan, T.; Livingston, E.H.; Snell, P.G.; Grundy, S.M.; Abate, N. Insulin resistance and body fat distribution in South Asian men compared to Caucasian Men. PLoS One 2007, 2, e812.

75. Jonathan, C.K. Wells commentary: Why are South Asians susceptible to central obesity? The El Niño hypothesis. Int. J. Epidemiol. 2007, 36, 226-227.

76. Hughes, K.; Aw, T.; Kuperan, P.; Choo, M. Central obesity, insulin resistance, syndrome X, lipoprotein (a) and cardiovascular risk in Indians, Malays, and Chinese in Singapore. J. Epidemiol. Community Health 1997, 51, 394-399.

77. Kamath, S.K.; Hussain, E.A.; Amin, D.; Mortillaro, E.; West, B.; Peterson, C.T.; Aryee, F.; Murillo, G.; Alekel, D.L. Cardiovascular disease risk factors in 2 distinct ethnic groups: Indian and Pakistani compared with American premenopausal women. Am. J. Clin. Nutr. 1999, 69, 621-631.

78. De Koning, L.; Merchant, A.T.; Pogue, J.; Anand, S.S. Waist circumference and waist-to-hip ratio as predictors of cardiovascular events: Meta-regression analysis of prospective studies. Eur. Heart J. 2007, 28, 850-856.

79. Raji, A.; Seely, E.W.; Arky, R.A.; Simonson, D.C. Body fat distribution and insulin resistance in healthy Asian Indians and Caucasians. J. Clin. Endocrinol. Metab. 2001, 86, 5366-5371.

80. Vega, G.L. Obesity, the metabolic syndrome, and cardiovascular disease. Am. Heart J. 2001, 142, 1108-1116.

81. Misra, A.; Misra, R.; Wijesuriya, M.; Banerjee, D. The metabolic syndrome in South Asians: Continuing escalation \& possible solutions. Indian J. Med. Res. 2007, 125, 345-354.

82. Goel, R.; Misra, A.; Kondal, D.; Pandey, R.M.; Vikram, N.K.; Wasir, J.S.; Dhingra, V.; Luthra, K. Identification of insulin resistance in Asian Indian adolescents: Classification and regression tree (CART) and logistic regression based classification rules. Clin. Endocrinol. (Oxf.) 2009, 70, 717-724.

83. Goel, K.; Gupta, N.; Misra, A.; Poddar, P.; Pandey, R.M.; Vikram, N.K.; Wasir, J.S. Predictive equations for body fat and abdominal fat with DXA and MRI as reference in Asian Indians. Obesity (Silver Spring) 2008, 16, 451-456.

84. Goel, K.; Misra, A.; Vikram, N.K.; Poddar, P.; Gupta, N. Subcutaneous abdominal adipose tissue is associated with the metabolic syndrome in Asian Indians independent of intra abdominal and total body fat of body. Heart 2010, 96, 579-583.

85. See, R.; Abdullah, S.M.; McGuire, D.K.; Khera, A.; Patel, M.J.; Lindsey, J.B.; Grundy, S.M.; de Lemos, J.A. The association of differing measures of overweight and obesity with prevalent atherosclerosis: The Dallas Heart Study. J. Am. Coll. Cardiol. 2007, 50, 752-759. 
86. Victor, R.G.; Haley, R.W.; Willett, D.L.; Peshock, R.M.; Vaeth, P.C.; Leonard, D.; Basit, M.; Cooper, R.S.; Iannacchione, V.G.; Visscher, W.A.; et al. The Dallas Heart Study: A population-based probability sample for the multidisciplinary study of ethnic differences in cardiovascular health. Am. J. Cardiol. 2004, 93, 1473-1480.

87. Ian, J.; Neeland, I.J.; Turer, A.T.; Colby, R.; Ayers, M.S.; Tiffany, M.; Wiley, P.; Gloria, L.; Farzaneh-Far, R.; Grundy, S.M.; et al. Dysfunctional adiposity and the risk of pre-diabetes and type 2 diabetes in obese adults. JAMA 2012, 308, 1150-1159.

88. Vega, G.L.; Adams-Huet, B.; Peshock, R.;Willett, D.; Shah, B.; Grundy, S.M. Influence of body fat content and distribution on variation in metabolic risk. J. Clin. Endocrinol. Metab. 2006, 29, $1414-1416$.

89. Liu, J.; Grundy, S.M.; Wang, W.; Smith, S.C., Jr.; Gloria, L.V.; Zhaosa, W.; Zhechun, Z.; Wenhua, W.; Dong, W. Ten-year risk of cardiovascular incidence related to diabetes, prediabetes, and the metabolic syndrome. Am. Heart J. 2007, 153, 552-558.

90. Yusuf, S.; Hawken, S.; Ounpuu, S.; Bautista, L.; Franzosi, M.G.; Commerford, P.; Lang, C.C.; Rumboldt, Z.; Onen, C.L.; Lisheng, L.; et al. Obesity and the risk of myocardial infarction in 27,000 participants from 52 countries: A case-control study. Lancet 2005, 366, 1640-1649.

91. Garg, A.; Misra, A. Hepatic steatosis, insulin resistance, and adipose tissue disorders. J. Clin. Endocrinol. Metab. 2002, 87, 3019-3022.

92. Luthra, A.; Nigam, P.; Misra, A. Metabolic correlates of non-alcoholic fatty liver disease and management issues: A perspective for Asian Indians. Diabetes Metab. Syndr. Res. Rev. 2007, 1, 279-285.

93. Bajaj, S.; Nigam, P.; Luthra, A.; Pandey, R.M.; Kondal, D.; Bhatt, S.P.; Wasir, J.S.; Misra, A. Insulin resistance, metabolic co-variates and prediction score in non-alcoholic fatty liver disease: A Case-control study. Indian J. Med. Res. 2009, 129, 285-292.

94. Sharma, R.; Sinha, S.; Danishad, K.A.; Vikram, N.K.; Gupta, A.; Ahuja, V.; Jagannathan, N.R.; Pandey, R.M.; Misra, A. Investigation of hepatic gluconeogenesis pathway in non-diabetic Asian Indians with non-alcoholic fatty liver disease using in vivo $\left({ }^{31} \mathrm{P}\right)$ phosphorus magnetic resonance spectroscopy. Atherosclerosis 2009, 203, 291-297.

95. Petersen, K.F.; Dufour, S.; Feng, J.; Befroy, D.; Dziura, J.; Dalla Man, C.; Cobelli, C.; Shulman, G.I. Increased prevalence of insulin resistance and non-alcoholic fatty liver disease in Asian Indian men. Proc. Natl. Acad. Sci. USA 2006, 103, 18273-18277.

96. Petersen, K.F.; Hendler, R.; Price, T.; Perseghin, G.; Rothman, D.L.; Held, N.; Amatruda, J.M.; Shulman, G.I. 13C/31P NMR studies on the mechanism of insulin resistance in obesity. Diabetes 1998, 47, 381-386.

97. Perseghin, G.; Scifo, P.; de Cobelli, F.; Pagliato, E.; Battezzati, A.; Arcelloni, C.; Vanzulli, A.; Testolin, G.; Pozza, G.; del Maschio, A.; et al. Intra-myocellular triglyceride content is a determinant of in vivo insulin resistance in humans: A $1 \mathrm{H}-13 \mathrm{C}$ nuclear magnetic resonance spectroscopy assessment in offspring of type 2 diabetic parents. Diabetes 1999, 48, 1600-1606.

98. Misra, A.; Sinha, S.; Kumar, M.; Jagannathan, N.R.; Pandey, R.M. Proton magnetic resonance spectroscopy study of soleus muscle in non-obese healthy and type 2 diabetic Asian Northern Indian males: High intra-myocellular lipid content correlates with excess body fat and abdominal obesity. Diabet. Med. 2003, 20,361-367. 
99. Sinha, S.; Misra, A.; Kumar, V.; Jagannathan, N.R.; Bal, C.S.; Pandey, R.M.; Singhania, R.; Deepak. Proton magnetic resonance spectroscopy and single photon emission computed tomography study of the brain in asymptomatic young hyperlipidaemic Asian Indians in North India show early abnormalities. Clin. Endocrinol. (Oxf.) 2004, 61, 182-189.

100. Sinha, S.; Misra, A.; Rathi, M.; Kumar, V.; Pandey, R.M.; Luthra, K.; Jagannathan, N.R. Proton magnetic resonance spectroscopy and biochemical investigation of type 2 diabetes mellitus in Asian Indians: Observation of high muscle lipids and C-reactive protein levels. Magn. Reson. Imaging 2009, 27, 94-100.

101. Garg, A.; Misra, A. Lipodystrophies: Rare disorders causing metabolic syndrome. Endocrinol. Metab. Clin. N. Am. 2004, 33, 305-331.

102. Mallon, P.W.; Wand, H.; Law, M.; Miller, J.; Cooper, D.A.; Carr, A. Buffalo hump seen in HIV-associated lipodystrophy is associated with hyperinsulinemia but not dyslipidemia. J. Acquir. Immune Defic. Syndr. 2005, 38, 156-162.

103. Haque, W.A.; Oral, E.A.; Dietz, K.; Bowcock, A.M.; Agarwal, A.K.; Garg, A. Risk factors for diabetes in familial partial lipodystrophy, Dunnigan variety. Diabetes Care 2003, 26, 1350-1355.

104. Misra, A.; Jaiswal, A.; Shakti, D.; Wasir, J.; Vikram, N.K.; Pandey, R.M.; Kondal, D.; Bhushan, B. Novel phenotypic markers and screening score for the metabolic syndrome in adult Asian Indians. Diabetes Res. Clin. Pract. 2008, 79, e1-e5.

105. Weyer, C.; Foley, J.E.; Bogardus, C.; Tataranni, P.A.; Pratley, R.E. Enlarged subcutaneous abdominal adipocyte size, but not obesity itself, predicts type II diabetes independent of insulin resistance. Diabetologia 2000, 43, 1498-1506.

106. Grundy, S.M.; Vega, G.L. Two different views of the relationship of hyper-triglyceridemia to coronary heart disease: Implications for treatment. Arch. Intern. Med. 1992, 152, 28-34.

107. Vega, G.L. Management of atherogenic dyslipidemia of the metabolic syndrome: Evolving rationale for combined drug therapy. Endocrinol. Metab. Clin. N. Am. 2004, 33, 525-544.

108. Chandalia, M; Deedwania, P.C. Coronary heart disease and risk factors in Asian Indians. Adv. Exp. Med. Biol. 2001, 498, 27-34.

109. Kulkarni, K.R.; Markovitz, J.H.; Nanda, N.C.; Segrest, J.P. Increased prevalence of smaller and denser LDL particles in Asian Indians. Arterioscler. Thromb. Vasc. Biol. 1999, 19, 2749-2755.

110. Abate, N.; Chandalia, M.; Snell, P.G.; Grundy, S.M. Adipose tissue metabolites and insulin resistance in non diabetic Asian Indian men. J. Clin. Endocrinol. Metab. 2004, 89, 2750-2755.

111. Abbasi, J.W.; Kulkarni, K.R.; Lamendola, C.; Mc Laughlin, T.L. Multiple lipoprotein abnormalities associated with insulin resistance in healthy volunteers are identified by the vertical auto profile-II methodology. Clin. Chem. 2003, 49, 1014-1017.

112. Chandalia, M.; Mohan, V.; Adams-Huet, B.; Deepa, R.; Abate, N. Ethnic difference in sex gap in high-density lipoprotein cholesterol between Asian Indians and Whites. J. Investig. Med. 2008, 56, 574-580.

113. Ajjan, R.; Carter, A.M.; Somani, R.; Kain, K.; Grant, P.J. Ethnic differences in cardiovascular risk factors in healthy Caucasian and South Asian individuals with the metabolic syndrome. J. Thromb. Haemost. 2007, 5, 754-760. 
114. Williams, E.D.; Kooner, I.; Steptoe, A.; Kooner, J.S. Psychosocial factors related to cardiovascular disease risk in UK South Asian men: A preliminary study. Br. J. Health Psychol. 2007, 12, 559-570

115. Smith, J.; Al-Amri, M.; Sniderman, A.; Cianflone, K. Leptin and adiponectin in relation to body fat percentage, waist to hip ratio and the apoB/apoA1 ratio in Asian Indian and Caucasian men and women. Nutr. Metab. (Lond.) 2006, 3, 18.

116. Somani, R.; Grant, P.J.; Kain, K.; Catto, A.J.; Carter, A.M. Complement C3 and C-reactive protein are elevated in South Asians independent of a family history of stroke. Stroke 2006, 37, 2001-2006.

117. Bhalodkar, N.C.; Blum, S.; Rana, T.; Kitchappa, R.; Bhalodkar, A.N.; Enas, E.A. Comparison of high-density and low-density lipoprotein cholesterol subclasses and sizes in Asian Indian women with Caucasian women from the Framingham Offspring Study. Clin. Cardiol. 2005, 28, 247-251.

118. Forouhi, N.G.; Sattar, N.; McKeigue, P.M. Relation of C-reactive protein to body fat distribution and features of the metabolic syndrome in Europeans and South Asians. Int. J. Obes. Relat. Metab. Disord. 2001, 25, 1327-1331.

119. Chambers, J.C.; Eda, S.; Bassett, P.; Karim, Y.; Thompson, S.G.; Gallimore, J.R.; Pepys, M.B.; Kooner, J.S. C-reactive protein, insulin resistance, central obesity, and coronary heart disease risk in Indian Asians from the United Kingdom compared with European whites. Circulation 2001, 104, 145-150.

120. Enas, E.A.; Garg, A.; Davidson, M.A.; Nair, V.M.; Huet, B.A.; Yusuf, S. Coronary heart disease and its risk factors in first-generation immigrant Asian Indians to the United States of America. Indian Heart J. 1996, 48, 343-353.

121. McKeigue, P.M.; Shah, B.; Marmot, M.G. Relation of central obesity and insulin resistance with high diabetes prevalence and cardiovascular risk in South Asians. Lancet 1991, 337, 382-386.

122. McKeigue, P.M.; Marmot, M.G.; Court, Y.D.S.; Cottier, D.E.; Rahman, S.; Riemersma, R.A. Diabetes, hyperinsulinaemia, and coronary risk factors in Bangladeshis in east London. Br. Heart J. 1988, 60, 390-396.

123. Ehtisham, S.; Crabtree, N.; Clark, P.; Shaw, N.; Barrett, T. Ethnic differences in insulin resistance and body composition in United Kingdom adolescents. J. Clin. Endocrinol. Metab. 2005, 90, 3963-3969.

124. Whincup, P.H.; Gilg, J.A.; Papacosta, O.; Seymour, C.; Miller, G.J.; Alberti, K.G.; Cook, D.G. Early evidence of ethnic differences in cardiovascular risk: Cross sectional comparison of British South Asian and white children. BMJ 2002, 324, 635.

125. Bhardwaj, S.; Passi, S.J.; Misra, A. Overview of trans fatty acids: Biochemistry and health effects. Diabetes Metab. Syndr. 2011, 5, 161-164.

126. Chapter 4 Trends in Urbanisation. Available online: http://www.censusindia.gov.in/2011-provresults/paper2-vo12/data_files/Mizoram/Chapter_4.pdf (accessed on 15 July 2011).

127. Family Welfare Statistics in India. 2011. Available online: http://mohfw.nic.in/ WriteReadData/1892s/972971120FW\%20Statistics\%202011\%20Revised\%2031\%2010\%2011.pdf (accessed on 17 January 2013). 
128. Misra, A.; Ganda, O.P. Migration and its impact on adiposity and type 2 diabetes. Nutrition 2007, 23, 696-708.

129. Hayes, L.; White, M.; Unwin, N.; Bhopal, R.; Fischbacher, C.; Harland, J.; Alberti, K.G. Patterns of physical activity and relationship with risk markers for cardio vascular disease and diabetes in Indian, Pakistani, Bangladeshi and European adults in a UK population. J. Public Health Med. 2002, 24, 170-178.

130. Gulati, S.; Misra, A.; Colles, S.L.; Kondal, D.; Gupta, N.; Goel, K.; Bansal, S.; Mishra, M.; Madkaikar, V.; Bhardwaj, S. Dietary intakes and familial correlates of overweight/obesity: A four cities study in India. Ann. Nutr. Metab. 2013, 62, 279-290.

131. Bhatt, S.P.; Nigam, P.; Misra, A.; Guleria, R.; Luthra, K.; Jain, S.K.; Qadar Pasha, M.A. Association of the Myostatin gene with obesity, abdominal obesity and low lean body mass and in non-diabetic Asian Indians in North India. PLoS One 2012, 7, e40977.

132. Sharma, M.; Misra, A.; Vikram, N.; Bhatt, S.; Chhabra, S.P.; Garg, N.; Pandey, RM.; Upadhyay, A.D.; Luthra, K. Genotype of the LMNA 1908C $>$ T variant is associated with generalized obesity in Asian Indians in North India. Clin. Endocrinol. (Oxf.) 2011, 75, 642-649.

133. Tabassum, R.; Jaiswal, A.; Chauhan, G.; Dwivedi, O.P.; Ghosh, S.; Marwaha, R.K.; Tandon, N.; Bhardwaj, D. Genetic variant of $A M D 1$ is associated with obesity in Urban Indian Children. PLoS One 2012, 7, e33162.

134. Bhatt, S.P.; Nigam, P.; Misra, A.; Guleria, R.; Luthra, K.; Vidya, M. SREBP-2 1784 G/C genotype is associated with non-alcoholic fatty liver disease in north Indians. Dis. Markers 2011, 31, 371-377.

135. Bhatt, S.P.; Nigam, P.; Misra, A.; Guleria, R.; Luthra, K.; Pandey, R.M.; Pasha, M.A.Q. Association of peroxisome proliferator activated receptor- $\gamma$ gene with non-alcoholic fatty liver disease in Asian Indians residing in north India. Gene 2013, 512, 143-147.

136. Tabassum, R.; Mahajan, A.; Chauhan, G.; Dwivedi, O.P.; Ghosh, S.; Tandon, N.; Bhardwaj, D. Evaluation of DOK5 as a susceptibility gene for type 2 diabetes and obesity in North Indian population. BMC Med. Genet. 2010, 11, 35.

137. Kumar, P.; Luthra, K.; Dwivedi, M.; Behl, V.K.; Pandey, R.M.; Misra, A. Apolipoprotein E gene polymorphisms in patients with premature myocardial infarction: A case-controlled study in Asian Indians in North India. Ann. Clin. Biochem. 2003, 40, 382-387.

138. Miller, M.; Rhyne, J.; Chen, H.; Beach, V.; Ericson, R.; Luthra, K.; Dwivedi, M.; Misra, A. APOC3 promoter polymorphisms C-482T and T-455C are associated with the metabolic syndrome. Arch. Med. Res. 2007, 38, 444-451.

139. Meena, K.; Misra, A.; Vikram, N.; Ali, S.; Pandey, R.M.; Luthra, K. Cholesterol ester transfer protein and apolipoprotein E gene polymorphisms in hyperlipidemic Asian Indians in North India. Mol. Cell. Biochem. 2011, 352, 189-196.

140. Misra, A.; Sharma, R.; Gulati, S.; Joshi, S.R.; Sharma, V.; Ghafoorunissa; Ibrahim, A.; Joshi, S.; Laxmaiah, A.; Kurpad, A.; et al. Consensus dietary guidelines for healthy living and prevention of obesity, the metabolic syndrome, diabetes, and related disorders in Asian Indians. Diabetes Technol. Ther. 2011, 13, 683-694. 
141. Misra, A.; Nigam, P.; Hills, A.P.; Chadha, D.S.; Sharma, V.; Deepak, K.K.; Vikram, N.K.; Joshi, S.; Chauhan, A.; Khanna, K.; et al. Consensus physical activity guidelines for Asian Indians. Diabetes Technol. Ther. 2012, 14, 83-98.

142. Ramachandran, A.; Snehalatha, C.; Yamuna, A.; Mary, S.; Ping, Z. Cost-effectiveness of the interventions in the primary prevention of diabetes among asian indians within-trial results of the Indian Diabetes Prevention Programme (IDPP). Diabetes Care 2007, 30, 2548-2552.

143. Ramachandran, A.; Snehalatha, C. Diabetes prevention programs. Med. Clin. N. Am. 2011, 95, 353-372.

144. Shah, P.; Misra, A.; Gupta, N.; Hazra, D.K.; Gupta, R.; Seth, P.; Agarwal, A.; Gupta, A.K.; Jain, A.; Kulshreshta, A.; et al. Improvement in nutrition-related knowledge and behaviour of urban Asian Indian school children: Findings from the 'Medical education for children/Adolescents for Realistic prevention of obesity and diabetes and for healthy aGeing' (MARG) intervention study. Br. J. Nutr. 2010, 104, 427-436.

145. Singhal, N.; Misra, A.; Shah, P.; Gulati, S. Effects of controlled school-based multi-component model of nutrition and lifestyle interventions on behavior modification, anthropometry and metabolic risk profile of urban Asian Indian adolescents in North India. Eur. J. Clin. Nutr. 2010, 64, 364-373.

146. Singhal, N.; Misra, A.; Shah, P.; Gulati, S.; Bhatt, S.P.; Sharma, S.; Pandey, R.M. Impact of intensive school-based nutrition education and lifestyle interventions on insulin resistance, $\beta$-cell function, disposition index, and subclinical inflammation among Asian Indian adolescents: A controlled intervention study. Metab. Syndr. Relat. Disord. 2011, 9, 143-150.

147. Singhal, N.; Misra, A. A school-based intervention for diabetes risk reduction. N. Engl. J. Med. 2010, 363, 1769-1770.

(C) 2013 by the authors; licensee MDPI, Basel, Switzerland. This article is an open access article distributed under the terms and conditions of the Creative Commons Attribution license (http://creativecommons.org/licenses/by/3.0/). 